\title{
Candida floccosa sp. nov., a novel methanol-assimilating yeast species
}

\author{
Gábor Péter, Dénes Dlauchy and Judit Tornai-Lehoczki \\ National Collection of Agricultural and Industrial Micro-organisms, Corvinus University of \\ Budapest, Faculty of Food Sciences, Somlói út 14-16, H-1118 Budapest, Hungary
}

Correspondence

Gábor Péter

gabor.peter@uni-corvinus.hu
The currently known ascosporulating methanol-assimilating yeast species belong to the genera Ascoidea and Pichia (Kurtzman \& Fell, 1998) and to some of the offspring genera separated from Pichia, i.e. Ogataea, Kuraishia (Yamada et al., 1994) and Komagataella (Yamada et al., 1995). The methylotrophic yeast species with unknown sexual reproduction are also of ascomycetous affinity and are currently assigned to the heterogeneous genus Candida (Meyer et al., 1998). In the present paper, we report on the isolation of three methylotrophic yeast strains from fluxes of oak trees of different geographical locations that share similar phenotypic and genotypic characters but differ from all hitherto described yeast species. Based on the abovementioned three strains, we propose Candida floccosa as a novel methanolassimilating yeast species.

Strains NCAIM Y.01579 and NCAIM Y. $01581^{\mathrm{T}}$ ( =CBS $10307^{\mathrm{T}}=$ NRRL Y-27951 ${ }^{\mathrm{T}}$ ) were isolated from the same flux sample of a sessile oak (Quercus petrea), collected from Pilis Mountain, Hungary, by a two-step enrichment in methanol-containing broth as described by Dlauchy et al. (2003). The isolate UWOPS $03-345 y 3$ was recovered from a flux of a red oak (Quercus rubra), collected from Long Point, Ontario, Canada. The strains were characterized with standard methods described by Yarrow (1998). Casein hydrolysis was tested with the method of Ahearn et al. (1968) with the modifications of Phaff et al. (1994). Lipolytic activity was determined according to Phaff et al. (1997). Sexual reactivity was studied by mixing actively growing cultures of the three investigated strains on acetate, cornmeal, potato dextrose, $2 \%$ malt extract and YM agars. The mixtures were incubated at room temperature $\left(20-25^{\circ} \mathrm{C}\right)$ and at $15^{\circ} \mathrm{C}$ and examined regularly by microscope up to 25 days. The

The GenBank/EMBL/DDBJ accession number for the sequence of the D1/D2 domain of the 26S rDNA of strain NCAIM Y.01581 ${ }^{\top}$ is AY069955.
D1/D2 domain of the large subunit (26S) rDNA from selected strains was sequenced as described by Kurtzman \& Robnett (1998). Sequence similarity searching was performed against the GenBank sequence database using the BLAST 2.2.12 database search program (Altschul et al., 1997). The sequences generated during this study along with sequences of related species retrieved from GenBank were aligned and a phylogenetic tree was constructed by the neighbour-joining method (Saitou \& Nei, 1987) using the CLUSTAL_X 1.81 program (Thompson et al., 1997). Bootstrap support for the tree was determined from 1000 replications.

The three investigated strains exhibited different colony and micromorphology. NCAIM Y.01579 and UWOPS 03-345y3 formed butyrous smooth colonies on malt extract agar, while the texture of NCAIM Y. $01581^{\mathrm{T}}$ was slightly tough, membranous, rough and folded. All strains formed pseudohyphae on cornmeal agar after 10 days, but the latter strain did so more vigorously than the other two. Similarly all strains formed small or large clusters in malt extract (without agitation, Fig. 1) and at least in some of the carbon assimilation tubes (incubated with agitation), giving a flocculent character to the liquid cultures, but the flocculation was most pronounced in the case of strain NCAIM Y. $01581^{\mathrm{T}}$. This duality among the morphology of the strains has dated back to the time of their isolation.

There were some minor differences amongst the conventionally tested taxonomic characteristics of the three strains of the novel species but these differences were usually limited to the intensity and the speed of the reactions. Notably, the Canadian isolate grew on succinate as a sole carbon source, while the two Hungarian ones did not.

The sequences of the D1/D2 domains of the large subunit rDNA of the strain isolated in Canada (UWOPS 03-345y3) 


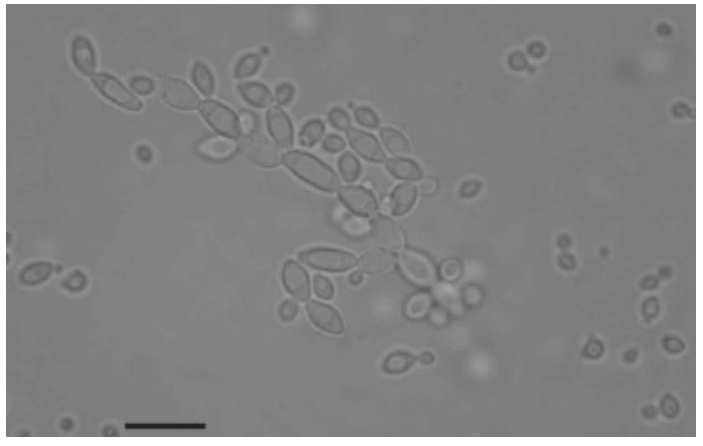

Fig. 1. Clusters of budding cells of Candida floccosa strain NCAIM Y. $01581^{\top}$ (malt extract, 3 days, $25^{\circ} \mathrm{C}$ ). Bar, $10 \mu \mathrm{m}$.

and one of the two strains recovered in Hungary (NCAIM Y.01581 ${ }^{\mathrm{T}}$ ) were determined. A sequence similarity search performed against the GenBank sequence database gave the closest sequence to be that of Candida hungarica NCAIM Y. $01507^{\mathrm{T}}$. There are 32 substitutions and 10 gaps on the corresponding $562 \mathrm{bp}$ fragment between the D1/D2 sequences of NCAIM Y.01581 ${ }^{\mathrm{T}}$ and that of the type strain of $C$. hungarica. Considering the guideline given by Kurtzman \& Robnett (1998), i.e. distinct species usually exhibit $1 \%$ or more sequence difference in this region, it can be concluded that NCAIM Y.01581 ${ }^{\mathrm{T}}$ represents a wellseparated yet undescribed yeast species. The phylogenetic placement of the novel species is shown in Fig. 2. Although

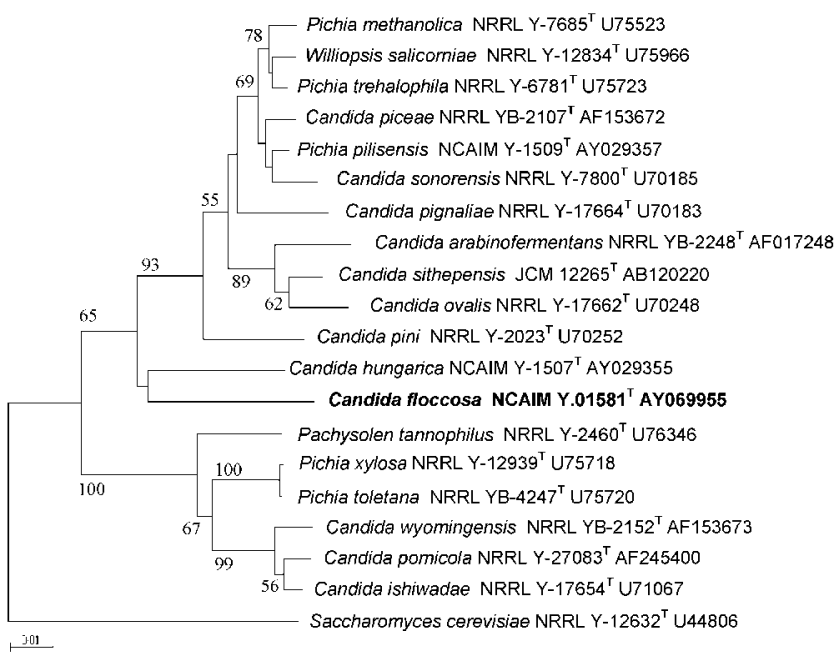

Fig. 2. Phylogenetic tree showing the placement of Candida floccosa sp. nov. NCAIM Y.01581 ${ }^{\top}$ and some closely related species based on analysis of the D1/D2 domain of large subunit (26S) rDNA. Sequences not generated during this study were obtained from GenBank. The tree was constructed by neighbour-joining analysis of aligned sequences. Numbers at nodes indicate percentage of bootstrap sampling from 1000 replications. Bar, $1 \%$ nucleotide sequence divergence. isolated on another continent, UWOPS 03-345y3 shared an identical D1/D2 sequence with NCAIM Y.01581 ${ }^{\mathrm{T}}$.

In the case of the strains investigated in this study, conventional physiological tests are also suitable to separate the novel species from the other methanol-assimilating yeast species. It can easily be distinguished from C. hungarica, the most closely related yeast species on the basis of the D1/D2 sequences, by numerous assimilation tests (Table 1).

Although all three strains of the novel species studied were isolated from oak flux, the species does not seem to be common in this habitat, e.g. the two Hungarian isolates were recovered from a single sample, other strains of the species have not been found again in fluxes collected in Hungary, in spite of the use of a methanol-enrichment technique and the screening of numerous additional samples, including over 100 oak fluxes. Likewise, the Canadian isolate was found only once in several hundred strains collected from the fluxes of oaks and other tree species in North America (M. A. Lachance, personal communication).

\section{Latin diagnosis of Candida floccosa Péter, Dlauchy \& Tornai-Lehoczki sp. nov.}

In extracto malti post dies tres ad $25^{\circ} \mathrm{C}$ cellulae sunt subglobosae, ellipsoideae, elongatae vel apiculatae $[1 \cdot 8-5 \cdot 0$ $(6 \cdot 0) \times 2 \cdot 3-6 \cdot 8(10) \mu \mathrm{m}]$, undiqua gemmantes, singulae, binae, catenis curtis vel racemis conexae. Pellicula vel orbis non continuus et sedimentum formantur. In agaro malti post dies tres in $25^{\circ} \mathrm{C}$ cultura est butyrosa vel membranea, cremea glabra vel rugosa, leviter nitida vel opaca. Margo coloniae integra vel leviter undulata. In agaro Zea maydis confecto post dies 10 in $25^{\circ} \mathrm{C}$ pseudomycelium formatur, mycelium verum

Table 1. Phenotypic characteristics that differentiate C. floccosa sp. nov. and C. hungarica

+ , Positive; -, negative; w, weak.

\begin{tabular}{|lcc|}
\hline Characteristic & C. floccosa & C. hungarica \\
\hline Assimilation of carbon compounds & & \\
D-Ribose & - & + \\
D-Xylose & - & + \\
L-Rhamnose & + & - \\
Cellobiose & - & + \\
Salicin & - & + \\
Lactose & - & + \\
Ribitol & - & + \\
Citrate & + or w & - \\
Propane-1,2-diol & + & - \\
Butane-2,3-diol & + & - \\
Assimilation of nitrogen compounds & & \\
Potassium nitrate & - & + \\
Sodium nitrite & - & - \\
Glucosamine (as nitrogen source) & + & + \\
\hline
\end{tabular}


non formatur. Ascosporae nullae. D-Glucosum (exigue, lente, variabile) fermentatur, D-galactosum, maltosum, sucrosum, lactosum, raffinosum et trehalosum non fermentantur. L-Sorbosum, D-glucosaminum, N-acetyl-D-glucosaminum, D-arabinosum (lente vel tarde, variabile), L-rhamnosum, sucrosum (variabile), maltosum, trehalosum, melezitosum (exigue, lente, variabile), glycerolum, xylitolum (exigue, lente, variabile), D-glucitolum, D-mannitolum, glucono $\delta$-lactonum (lente), DL-lactatum, succinatum (variabile), citratum, methanolum, ethanolum, propane-1,2-diolum, butane-2,3diolum assimilantur, at non D-galactosum, D-ribosum, Dxylosum, L-arabinosum, methyl $\alpha$-D-glucosidum, cellobiosum, salicinum, arbutinum, melibiosum, lactosum, raffinosum, inulinum, amylum solubile, meso-erythritolum, ribitolum, L-arabinitolum, galactitolum, myo-inositolum, 2-ketogluconicum, D-gluconicum, D-glucuronicum, D-galacturonicum, hexadecanum. Ethylaminum hydrochloricum, lysinum, cadaverinum dihydrochloricum, glucosaminum assimilantur at non kalium nitricum, natrium nitrosum, creatinum, creatininum. Materia amyloidea iodophila non formatur. Vitamina externa crescentiae sunt necessaria. Crescere potest in $30^{\circ} \mathrm{C}$ (lente, exigue), at non in $35^{\circ} \mathrm{C}$. In agaro extracto fermenti confecto 50 partes glucosi per centum non crescit. Parte una cycloheximidi per mille crescit. Ureum non finditur. Diazonium caeruleum B est negativum. Typus stirps NCAIM Y.01581 ${ }^{\mathrm{T}}\left(=\right.$ CBS $10307^{\mathrm{T}}=$ NRRL Y $\left.-27951^{\mathrm{T}}\right)$.

\section{Description of Candida floccosa Péter, Dlauchy \& Tornai-Lehoczki sp. nov.}

Candida floccosa (flocc'o.sa. L. fem. adj. floccosa full of flocks, of wool, woolly, referring to the flocculent characteristics of the investigated strains).

In $5 \%$ malt extract after 3 days at $25^{\circ} \mathrm{C}$, the cells are subglobose, ellipsoid or elongated, but a small portion of them are more or less lemon-shaped. They occur singly, in pairs, in short chains and in clusters, $1 \cdot 8-5 \cdot 0(6 \cdot 0) \times 2 \cdot 3-6 \cdot 8(10)$ $\mu \mathrm{m}$ in size. Vegetative reproduction proceeds by multilateral budding (Fig. 1). Incomplete pellicle or ring and a sediment are present. On $5 \%$ malt extract agar after 3 days at $25^{\circ} \mathrm{C}$, the streak culture is butyrous or membranous, slightly raised or more or less convex, cream coloured, smooth or rough and folded, slightly glistening or dull. The margin is entire or slightly undulating. On cornmeal agar after 10 days at $25^{\circ} \mathrm{C}$, pseudohyphae are formed; septate hyphae are absent. Ascospore formation has not been observed. Glucose fermentation is weak, slow and variable. D-Galactose, maltose, sucrose, lactose, raffinose and $\alpha, \alpha$-trehalose are not fermented. L-Sorbose, D-glucosamine, $\mathrm{N}$-acetyl-Dglucosamine, D-arabinose (slow and variable), L-rhamnose, sucrose (variable), maltose, $\alpha, \alpha$-trehalose, melezitose (weak, slow and variable), glycerol, xylitol (weak, slow and variable), D-glucitol, D-mannitol, glucono- $\delta$-lactone (slow), DL-lactate, succinate (variable), citrate, methanol, ethanol, propane-1,2-diol and butane-2,3-diol are assimilated; no growth occurs on D-galactose, D-ribose, D-xylose, L-arabinose, methyl $\alpha$-D-glucoside, cellobiose, salicin, arbutin, melibiose, lactose, raffinose, inulin, starch, meso-erythritol, ribitol, L-arabinitol, galactitol, myoinositol, 2-keto-D-gluconate, D-gluconate, D-glucuronate, D-galacturonate or hexadecane. Ethylamine hydrochloride, L-lysine, cadaverine dihydrochloride and glucosamine (as nitrogen source) are assimilated. Potassium nitrate, sodium nitrite, creatine and creatinine are not assimilated. The formation of amyloid material is negative. Growth in vitamin-free medium is negative. Growth at $30{ }^{\circ} \mathrm{C}$ is slow and at $37^{\circ} \mathrm{C}$ is negative. No growth occurs on $50 \%(\mathrm{w} / \mathrm{w})$ glucose/yeast extract agar, with $10 \% \mathrm{NaCl}$ or with $1 \%$ acetic acid. Growth with $0 \cdot 1 \%$ cycloheximide is positive. Urea hydrolysis, and colour reaction with diazonium blue $\mathrm{B}$ are negative. Gelatin liquefaction and casein hydrolysis are negative.

The type strain was recovered from flux of an oak (Quercus petrea), collected from Pilis Mountain, Hungary, and is maintained as NCAIM Y.01581 ${ }^{\mathrm{T}}\left(=\mathrm{CBS} 10307^{\mathrm{T}}=\mathrm{NRRL}\right.$ Y-27951 ${ }^{\mathrm{T}}$ ) in the National Collection of Agricultural and Industrial Micro-organisms in Budapest (Hungary).

\section{Acknowledgements}

This research was partly supported by the Bolyai János Research Scholarship of the Hungarian Academy of Sciences. We thank Marc-André Lachance for sharing sequence information and the gift of a yeast strain.

\section{References}

Ahearn, D. G., Meyers, S. P. \& Nichols, R. A. (1968). Extracellular proteases of yeasts and yeast-like fungi. Appl Microbiol 16, 1370-1374.

Altschul, S. F., Madden, T. L., Schäffer, A. A., Zhang, J., Zhang, Z., Miller, W. \& Lipman, D. J. (1997). Gapped BLAST and PSI-BLAST: a new generation of protein database search programs. Nucleic Acids Res 25, 3389-3402.

Dlauchy, D., Tornai-Lehoczki, J., Fülöp, L. \& Péter, G. (2003). Pichia (Komagataella) pseudopastoris sp. nov., a new yeast species from Hungary. Antonie van Leeuwenhoek 83, 327-332.

Kurtzman, C. P. \& Fell, J. W. (editors) (1998). The Yeasts, a Taxonomic Study, 4th edn. Amsterdam: Elsevier.

Kurtzman, C. P. \& Robnett, C. J. (1998). Identification and phylogeny of ascomycetous yeasts from analysis of nuclear large subunit (26S) ribosomal DNA partial sequences. Antonie van Leeuwenhoek 73, 331-371.

Meyer, S. A., Payne, R. W. \& Yarrow, D. (1998). Candida Berkhout. In The Yeasts, a Taxonomic Study, 4th edn, pp. 454-573. Edited by C. P. Kurtzman \& J. W. Fell. Amsterdam: Elsevier.

Phaff, H. J., Starmer, W. T., Lachance, M. A. \& Ganter, P. F. (1994). Candida caseinolytica sp. nov., a new species of yeast occurring in necrotic tissue of Opuntia and Stenocereus species in the southwestern United States and Baja California, Mexico. Int J Syst Bacteriol 44, 641-645.

Phaff, H. J., Blue, J., Hagler, A. N. \& Kurtzman, C. P. (1997). Dipodascus starmeri sp. nov., a new species of yeast occuring in cactus necroses. Int J Syst Bacteriol 47, 307-312.

Saitou, N. \& Nei, M. (1987). The neighbor-joining method: a new method for reconstructing phylogenetic trees. Mol Biol Evol 4, 406-425.

Thompson, J. D., Gibson, T. J., Plewniak, F., Jeanmougin, F. \& Higgins, D. G. (1997). The CLUSTAL_X windows interface: flexible 
strategies for multiple sequence alignment aided by quality analysis tools. Nucleic Acids Res 25, 4876-4882.

Yamada, Y., Maeda, K. \& Mikata, K. (1994). The phylogenetic relationships of the hat-shaped ascospore-forming, nitrate-assimilating Pichia species, formerly classified in the genus Hansenula Sydow et Sydow, based on the partial sequences of $18 \mathrm{~S}$ and $26 \mathrm{~S}$ ribosomal RNAs (Saccharomycetaceae): the proposals of three new genera, Ogataea, Kuraishia, and Nakazawaea. Biosci Biotechnol Biochem 58, $1245-1257$.
Yamada, Y., Matsuda, M., Maeda, K. \& Mikata, K. (1995). The phylogenetic relationships of methanol-assimilating yeasts based on the partial sequences of $18 \mathrm{~S}$ and $26 \mathrm{~S}$ ribosomal RNAs: the proposal of Komagataella gen. nov. (Saccharomycetaceae). Biosci Biotechnol Biochem 59, 439-444.

Yarrow, D. (1998). Methods for the isolation, maintenance and identification of yeasts. In The Yeasts, a Taxonomic Study, 4th edn, pp. 77-100. Edited by C. P. Kurtzman \& J. W. Fell. Amsterdam: Elsevier. 